DOI: https://doi.org/10.15688/jvolsu4.2021.2.13

UDC 94[323.2:719]“1918/1920"

Submitted: 24.08 .2019

LBC 63.3(2)

Accepted: 06.02.2020

\title{
PRACTICE OF MEMORIALIZATION OF THE ANTI-SOVIET MOVEMENT IN THE SOUTH OF RUSSIA DURING THE CIVIL WAR ${ }^{1}$
}

\author{
Anna N. Eremeeva \\ Southern Branch of Russian Research Institute for Cultural and Natural Heritage named after D.S. Likhachev, \\ Krasnodar, Russian Federation
}

\begin{abstract}
Introduction. The article is devoted to the memorialization of the anti-Soviet movement in the South of Russia, which took place during the Civil War. The author considers the approaches of Denikin and Cossack (Don and Kuban) governments to the glorification of the struggle against the Bolsheviks, the canonization of the leaders of this struggle, the creation of so-called places of memory. Methods and materials. The research is based on legislative acts and documentation records of anti-Soviet governments in the South of Russia. The unpublished documents are stored in central and regional archives of the Russian Federation and Hoover Institution Archives (USA). The other significant sources are periodicals, propaganda products, artistic texts of 1918-1920, and private correspondence. Analysis and results. The politics of memory of the "white" and Cossack governments was an important part of the official propaganda. It was aimed to legitimize and consolidate the anti-Bolshevik movement. During the Civil War, documents and other artifacts were actively collected for future archives and museums of the "liberation war". The Military-Historical Commission under Denikin Propaganda Department played an important role in this activity. Museums of the struggle against Bolshevism in the Kuban and Don were being formed at the initiative of Cossack governments. There were monumental, toponymical and other projects to perpetuate the memory of the anti-Bolshevik movement heroes. The presence of the opposing memorial narratives in the South of Russia was the result of serious contradictions between the main actors inside the anti-Bolshevik camp.

Key words: Civil War, Kuban, Don, White movement, Cossack governments, politics of memory, museums, monumental projects.

Citation. Eremeeva A.N. Practice of Memorialization of the Anti-Soviet Movement in the South of Russia During the Civil War. Vestnik Volgogradskogo gosudarstvennogo universiteta. Seriya 4. Istoriya. Regionovedenie. Mezhdunarodnye otnosheniya [Science Journal of Volgograd State University. History. Area Studies. International Relations], 2021, vol. 26, no. 2, pp. 171-183. (in Russian). DOI: https://doi.org/10.15688/jvolsu4.2021.2.13
\end{abstract}

УДК 94[323.2:719]“1918/1920”

Дата поступления статьи: 24.08.2019

ББК 63.3(2)

Дата принятия статьи: 06.02.2020

\section{ПРАКТИКИ МЕМОРИАЛИЗАЦИИ АНТИСОВЕТСКОГО ДВИЖЕНИЯ НА ЮГЕ РОССИИ В ГОДЫ ГРАЖДАНСКОЙ ВОЙНЫ ${ }^{1}$}

\author{
Анна Натановна Еремеева \\ Южный филиал Российского научно-исследовательского института \\ культурного и природного наследия им. Д.С. Лихачева, г. Краснодар, Российская Федерация
}


Аннотация. Статья посвящена мемориализации антисоветского движения на Юге России, происходившей непосредственно в условиях Гражданской войны. Цель работы - на основе документов, как опубликованных, так и пока не введенных в научный оборот, хранящихся в фондах Государственного архива Российской Федерации, Российского государственного военного архива, Государственного архива Краснодарского края, Государственного архива Ростовской области, Архива Гуверовского института (США), данных периодики и других источников, рассмотреть действия деникинского и казачьих (донского и кубанского) правительств, направленные на героизацию борьбы с большевиками, канонизацию ее лидеров, создание «мест памяти». Политика памяти «белого» и казачьих правительств являлась важной частью официальной пропаганды и собственной легитимации. Уже в процессе Гражданской войны происходил сбор документов и других артефактов для формирования архивных коллекций, музеев. Важную роль в этом играли Военно-историческая комиссия при деникинском Отделе пропаганды, а также инициативы отдельных лиц. Разрабатывались планы увековечения героев борьбы с большевиками посредством монументальных и топонимических инициатив. Был реализован крупный пропагандистский выставочный проект - передвижная Корниловская выставка. На Дону и Кубани создавались собственные музеи борьбы с большевизмом. Несмотря на попытки посредством коммеморации объединить участников антибольшевистской борьбы, идеологические противоречия между ними приводили к наличию оппонирующих мемориальных нарративов на Юге России. Мемориализация антисоветского движения, продолженная в эмиграции и в постсоветской России, на всех этапах вызывала острые дискуссии ввиду «конфликтов памяти».

Ключевые слова: Гражданская война, Кубань, Дон, Белое движение, казачьи правительства, политика памяти, музеи, монументальные проекты.

Цитирование. Еремеева А. Н. Практики мемориализации антисоветского движения на Юге России в годы Гражданской войны // Вестник Волгоградского государственного университета. Серия 4, История. Регионоведение. Международные отношения. -2021.- Т. 26, № 2.-C. 171-183. - DOI: https://doi.org/10.15688/jvolsu4.2021.2.13

Введение. Мемориальная политика одна из популярных тем исторических трудов последних десятилетий. Исследователи даже полагают, что можно говорить о «мемориальном повороте», развернувшемся на рубеже XX-XXI вв. в числе методологических поворотов, кардинально изменивших облик современной исторической науки [8, с. 59-60]. Мемориальные практики, учитывая сущность коммеморации, логично связываются с событиями прошлого. В представленной статье речь идет о мемориализации антисоветского движения непосредственно в процессе Гражданской войны, то есть о синхронном происходившим событиям производстве образов героев и героического. Воссоздаются, прежде всего, формирование музеев истории «освободительной войны», монументальные и топонимические проекты. Территориальные рамки исследования - Кубань и Дон, ставшие в годы Гражданской войны крупнейшими центрами антибольшевистского движения и одновременно возрождения казачьей государственности.

Для осмысления темы большое значение имеют многочисленные труды российских и зарубежных ученых по истории Граж- данской войны на Юге России, рассматривающие организацию и сущность «белой» и казачьей пропаганды, противоречия в антибольшевистском движении, биографии его лидеров, а также теоретические работы, осмысливающие сущность коммеморации. Политолог О.В. Малинова в связи с «неудобным юбилеем» - столетием революции произвела анализ нарративов мнемонических акторов политических сил, заинтересованных в особом понимании прошлого [9]. Данный анализ подтверждает сходство мемориальных нарративов современной России с текстами вековой давности. Одному из аспектов заявленной темы (истории создания музеев для увековечения истории антибольшевистской борьбы) посвящено несколько докладов на конференциях 2017-2018 гг. [4; 5; 23].

Методы, материалы. Источниковой базой исследования стали законодательные и подзаконные акты государственных образований Юга России, делопроизводственные материалы правительственных структур - военных, пропагандистских, ведомств народного просвещения. Частично они опубликованы (протоколы заседаний Кубанского краевого правительства, протоколы и стенограммы за- 
седаний Кубанских краевой и Законодательной Рад и др.). Однако многие документы, хранящиеся в фондах центральных и региональных архивов Российской Федерации, архива Гуверовского института (Стэнфордский университет, США), еще не введены в научный оборот. Большой интерес представляет деловая переписка по поводу сбора музейных экспонатов, подготовки праздников, всевозможных переименований, учреждения именных стипендий и пр. Ценными источниками являются периодические издания Юга России 1918-1920 гг., особенно газета «Приазовский край» и журнал «Донская волна», разнообразная пропагандистская продукция тех лет, фотографии, источники личного происхождения.

Специфика темы и ее источниковое обеспечение обусловили использование различных методов. Историко-генетический метод необходим для воссоздания целей, логики, эволюции коммемораций в условиях гражданского противостояния и противоречий внутри антибольшевистского лагеря. Сравнительно-исторический метод позволяет осознать сходство и различие в коммеморативных практиках ключевых акторов гражданского противостояния на Юге России. Проблематика и алгоритм исследования во многом сформированы трудами теоретиков исторической памяти. Особое значение имеют идеи П. Нора, касающиеся целенаправленности, а не спонтанности формирования мест памяти («нужно создавать архивы, нужно отмечать годовщины, организовывать празднования, произносить надгробные речи...» [10, с. 26]); в представленной статье они, по сути, раскрываются на конкретных примерах.

Анализ. Начало мемориализации антисоветского движения на Юге России, как целенаправленной политики увековечения определенных лиц и событий, относится к августу - сентябрю 1918 года. К тому времени в «арсенале» Добровольческой армии, кубанцев и донцов уже было участие в походах (прежде всего, в Ледяном, сплотившем противников большевизма), значительное количество павших на начальном этапе противостояния, в том числе лидеров Добровольческой армии и казачества (Л.Г. Корнилов, С.Л. Марков, Е.А. Волошинов, М.П. Богаевский, А.М. Каледин, А.М. Назаров, В.М. Чернецов, К.Л. Бардиж и др.).
Главным символом борьбы с большевизмом как для «добровольцев», так и для казаков стал Л.Г. Корнилов, погибший вблизи Екатеринодара. Почти сразу после освобождения города от «красных» председатель Кубанского краевого правительства Л.Л. Быч на заседании поднял вопрос об увековечивании памяти генерала Корнилова путем обустройства места его гибели [18, с. 132]. Вопросы ухода за символической могилой Л.Г. Корнилова и могилой его жены, превращение прилегающей территории в памятное место регулярно поднимались на уровне официальных инстанций, Комитета по увековечению памяти генерала Л.Г. Корнилова, общественных организаций, в прессе.

Известный столичный издатель Б.А. Суворин запечатлел и опубликовал в сентябре 1918 г. в номере 15 журнала «Донская волна» серию фотографий с места гибели Корнилова: акт передачи старого георгиевского знамени одному из новых кубанских полков в присутствии кубанского атамана А.П. Филимонова, генералов А.И. Деникина и И.П. Романовского (символизировавший единение «добровольцев» и казаков); дом, где был смертельно ранен Корнилов с намеренно не заштукатуренным следом от гранаты; генерал М.В. Алексеев у места гибели Корнилова после панихиды 18 августа 1918 г;; обрыв над Кубанью, «где испустил дух Л.Г. Корнилов».

Вообще, как справедливо отмечал американский историк-славист Л. Херец, культ смерти занимал центральное место в сознании «добровольцев». Смерть Корнилова рассматривалась в качестве модели для подражания. Лучшие полки гордо несли имена погибших или умерших героев, что не только выражало верность павшим вождям, но и утверждало принцип самопожертвования [27, p. 117-118].

Сакральный статус места постоянно подтверждался. Сюда приезжало высшее армейское руководство, проводились различные церемонии. Как отмечает В.Ж. Цветков, именно в отремонтированном здании «фермы», в которой находился штаб Л.Г. Корнилова, была создана экспозиция первого мемориального музея Белого движения на Юге России. В самой комнате на месте смертельного ранения генерала был установлен крест. На внутрен- 
ней стене «фермы» было сделано панно из венков, трехцветных лент, национального российского флага и оружия [23, с. 376$]$.

Первая годовщина со дня гибели Корнилова стала, по сути, первым масштабным событием в формирующемся календаре памятных дат эпохи Гражданской войны, впоследствии включившим в себя и годовщины победных сражений, и освобождений городов, отмечавшиеся (после предварительной подготовки) в форме общенародных праздников в течение одного-двух дней. Корниловская годовщина стала поводом для целой серии коммеморативных акций: панихид, посещений места гибели, памятных текстов в газетах и журналах (как «добровольческих», так и казачьих), изданий биографических брошюр, монументальных, топонимических, музейных инициатив.

К тому времени при деникинском Осведомительном агентстве развернула деятельность Комиссия для сбора военно-исторических материалов освободительной войны от большевиков (Военно-историческая комиссия) под руководством полковника М.В. Колобова, имевшего опыт подобной работы в годы Первой мировой войны, когда он возглавлял Комиссию по описанию боевых трофеев Русского воинства. Активную помощь Колобову в организации сбора и описания экспонатов оказывал полковник Я.М. Лисовой. «Программой-максимум» Комиссии было создание музея Возрождения России, который после победы «белых» должен был открыться в столице. Предполагалось наличие в музее пропагандистского и исторического подразделений, что соответствовало его актуальным и перспективным задачам. Планировалось создать отделы денежных знаков, карт, трофейный, оружейный, художественный. Экспонаты, поступавшие в комиссию, должны были быть снабжены заметкой о том, где, когда и при каких обстоятельствах тот или иной предмет был взят [7, л. 1-1 об.].

Ввиду приближавшейся годовщины гибели Корнилова Комиссией было анонсировано создание корниловского отдела в организуемом музее Возрождения России. В качестве экспонатов приветствовалось все, касающееся Корнилова и корниловцев. Многие фронтовые офицеры передали ценные документы, в том числе фотографический снимок «"Корнилов в гробу" с большевистской печатью и надписью на оборотной стороне» $[1$, с. 4].

Реальным результатом этой деятельности стала передвижная Корниловская выставка, работавшая с апреля по июнь 1919 г. в Екатеринодаре, Ростове-на-Дону, Таганроге, Новочеркасске. В архиве Гуверовского института в фонде одного из лидеров Белого движения на Севере России Евгения Миллера имеется конверт с 22 фотографиями выставки [26]. Репортажи, освещающие данное событие, публиковались в прессе. Воспроизведем его на примере Ростова-на-Дону.

Выставка открылась в ростовском кинотеатре «Солей» 12 (25) мая 1919 г. и работала там более двух недель, до 28 мая (10 июня). Открытию предшествовало торжественное заседание памяти Л.Г. Корнилова с участием представителей высшего военного и политического руководства, в том числе союзнического, корниловцев, прибывших с фронта, ректора Донского университета, профессоров, городского головы Ростова-на-Дону, начальников средних учебных заведений города, детей Л.Г. Корнилова. Председательствовал генерал В.3. Май-Маевский. Автор первого доклада Я.М. Лисовой и другие выступающие подчеркивали беззаветный патриотизм Корнилова, его роль в борьбе за восстановление государственности. Кроме торжественных речей в переполненном зале звучали стихи о России (в частности, М. Волошина «Святая Русь» и «Петроград», написанные в конце 1917 г., показывающие весь ужас междоусобицы), играл оркестр, выступали ведущие художественные силы города. Среди ценных экспонатов выставки - реликвии Л.Г. Корнилова - ордена, погоны, шинель, в которой генерал был смертельно ранен, папаха, стол, за которым он сидел в момент ранения, скамья с повреждениями от снаряда, резиновый бинт, которым был перевязан Корнилов. бинт со следами крови, осколки снаряда, найденные около фермы. Экспонировались фотографии походной жизни корниловцев, многочисленные портреты Л.Г. Корнилова, М.В. Алексеева, А.И. Деникина и их сподвижников, бюст Корнилова работы скульптора Г.И. Рихи [1, с. 4].

Литературно-документальный отдел, который курировал участник Ледяного похо- 
да, автор изданной под грифом Военно-исторической комиссии брошюры «Чем был Корнилов для России» журналист Б.А. Будилович, включал приказы и автографы Корнилова, карту похода, а также большевистские документы, «по-своему» освещающие его [1, с. 4].

Главным художественным экспонатом выставки стала картина Н.В. Харитонова «Смерть генерала Корнилова». Уже в процессе организации выставки начались переговоры о ее приобретении для будущего музея.

Газета «Приазовский край» сообщала о посещении выставки начальником Отдела пропаганды профессором К.Н. Соколовым (именно он инициировал аналогичную екатеринодарскую выставку), генералом А.И. Шкуро. Подробно освещался визит донского атамана А.П. Богаевского. Личная сопричастность атамана совместной освободительной борьбе «белых» и казачества подчеркивалась приведенной фразой Богаевского о том, что он может привести много подробностей, так как за пять минут до гибели Корнилова был у него с докладом [3, с. 2].

Выставка, вызвавшая повсеместно большой интерес посетителей и в процессе проведения пополнявшаяся все новыми экспонатами, стимулировала активизацию работы Военно-исторической комиссии. Ее члены выезжали на фронт за артефактами. Однако масштабных и резонансных проектов, подобных Корниловской выставке, организовать не удалось.

Материалы Военно-исторической комиссии (в том числе Корниловской выставки) частично были вывезены в 1920 г. Я.М. Лисовым за границу, где и устраивались выставки. В 1951 г. он сообщал Б.И. Николаевскому о передаче части коллекции в библиотеку Конгресса США, в военные музеи Великобритании, Нидерландов, Польши, о том, что «самая главная часть, более 2 тонн (5 500 фунтов) находится в Московской исторической публичной библиотеке в референс отделе... для исторических изысканий» [28]. Главная часть коллекции, о которой упоминал Я.М. Лисовой, вскоре была разделена и передана нескольким центральным архивохранилищам и книгохранилищам СССР.

Создание собственных музеев, отражавших историю Гражданской войны, было в пла- нах донцов и кубанцев. Первым шагом стало формирование соответствующих отделов в Донском музее (Новочеркасск) и Войсковом этнографическом и естественно-историческом музее (Екатеринодар), однако уже в 1919 г. выкристаллизовалась идея специализированных учреждений.

Для кубанского музея было выделено помещение в здании войскового штаба - в доме Акулова на углу улиц Красная и Крепостная. Директором музея назначили генералмайора П.П. Орлова - популяризатора казачьей истории, участника Ледяного похода, награжденного Крестом спасения Кубани. Куратором музея был Член Кубанского краевого правительства по военным делам: сначала генерал-майор В.Г. Науменко (в зарубежье он стал атаманом Кубанского казачьего войска и много сделал для сохранения казачьих регалий), затем его преемники - генерал-майоры С.П. Звягинцев и Л.М. Болховитинов. В марте 1920 г. С.П. Звягинцев сопровождал регалии и другие материалы Кубанского казачьего войска за границу.

Руководством музея были заготовлены шаблоны писем следующего содержания: «Милостивый государь! Озабочиваясь собрать в музей все достойное памяти потомства Кубанского казачества, все светлое по воспоминаниям переживаемых событий... просим прислать в музей Ваш портрет с автографом к нему» [20, л. 7]. Они были разосланы А.Г. Шкуро, С.Г. Улагаю, В.Л. Покровскому, С.М. Топоркову, А.П. Филимонову (как участнику Ледяного похода), П.Н. Врангелю.

Сохранилась копия с циркулярного предписания командующего Третьим конным корпусом генерал-лейтенанта А.Г. Шкуро от 29 сентября 1919 г.: «Член Кубанского краевого правительства по военным делам озабочиваясь, дабы сохранить в памяти потомства Кубанского казачьего войска воспоминания о переживаемых событиях, приступил к образованию музея в городе Екатеринодаре. В каждой части надо назначить лицо, кое бы из любви к казачеству и своему родному краю России, взяло бы на себя труд создать все то, что имеет отношение к осуществлению намеченной цели» [24, л. 1]. Обратим вниманиефрагмент со словами «из любви к казачеству и своему родному краю России» подчеркива- 
ет неприятие автором кубанского сепаратизма (А.И. Шкуро относился к тем, кто поддерживал «единонеделимцев»). К циркуляру приложен «Перечень желательных для музея предметов», распределенных по отделам. Например, в исторический отдел требовались научные труды, журналы военных действий, документы, очерки борьбы, списки потерь, письма, записки, дневники, биографии, стихи, песни, меткие выражения, в отдел пропаганды - «газеты, не исключая большевистских, прокламации, плакаты», в трофейный - знамена и значки, в оружейный - вооружение, отбитое оружие, снаряды, в художественный - картины, эскизы, портреты, не исключая большевистских, фотографии. Экспонатами предлагалось наполнить подотделы денежных знаков и картографический [24, л. 2].

Уполномоченным для сбора артефактов офицерам выдавались «открытые» листы. По итогам поездок писались отчеты с перечислением привезенного. Активность проявляло и население Кубани, присылавшее фотографии, письма, разнообразную печатную продукцию, в том числе изданную в первый период советской власти [20].

На Дону изначально координатором сбора экспонатов для будущего музея стал Отдел народного просвещения Всевеликого войска Донского. В циркуляре «О собирании материалов по переживаемому моменту» содержался призыв доставлять «все сведения о героях гражданской войны, рассказы очевидцев, списки предателей, фото...» [12, с. 34]. Отдел организационно и финансово поддержал инициативу приват-доцента Донского университета А.Н. Вознесенского по созданию «Архива современных событий», который должен был стать основой «музея или архива памятников и документов, касающихся истории войны и революции как в России вообще, так и на Дону в частности» [11, л. 31-31 об.].

В сентябре - октябре 1919 г. по инициативе командующего Донской армией В.И. Сидорина началась работа Комитета по устройству передвижной выставки памятников борьбы Дона с большевиками. Возглавил его атаман А.П. Богаевский. Из лаконичных телеграмм Сидорина Богаевскому, Богаевского начальнику отделения по сбору и систематизации документов войны становится ясно, что выставку, должную «представить возможно полно доблесть казачества», планировалось организовать в кратчайшие сроки и рекомендовалось «немедленно приступить к сбору материалов» [14, л. 21, 25]. Значительную их часть составили портреты участников антибольшевистского движения, а также плакаты: «За Великую Россию», «Зверства большевиков», «Мир и свобода в Совдепии», «В жертву Интернационалу» (переданы деникинским Отделом пропаганды), «Зверства большевиков на Дону», «Светлая тень Ермака благословляет ратные подвиги объединенного казачества, идущего на освобождение России», «Что несет народу большевизм», «Казак Кузьма Крючков» (передано Донским отделом осведомления), а также документы и плакаты из большевистского лагеря [13, л. 1-2]. Судя по данному списку, выставка должна была продемонстрировать единение донцов и «добровольцев» в борьбе против общего врага.

Скорее всего, ни кубанский Музей, ни донской Комитет так и не развернули выставочную деятельность ввиду ситуации на фронте.

Заслуживают внимания монументальные инициативы на Юге России. Самый ранний по времени проект был «запущен» на Дону. Атаман П.Н. Краснов 5 сентября 1918 г. издал приказ, предписывающий, согласно постановлению Большого Войскового круга, «в увековечение памяти героев Донской Земли, душу свою за ближних и за свободу Родного Края положивших во время настоящей гражданской войны, поставить в г. Новочеркасске на Соборной площади памятник героям освободительной войны и трем атаманам мученикам - избранникам народа в лице Войскового Круга, и за народ душу свою положившим генералу от кавалерии Алексею Максимовичу Каледину и Генерал-майору Анатолию Михайловичу Назарову, помощнику Донского Атамана Каледина Митрофану Петровичу Богаевскому, первому ставшему на место Войскового Наказного Атамана Атаманом по требованию народа, Войсковому старшине Волошинову, впоследствии зверски расстрелянному и замученному большевиками, и первому партизану Донскому, боровшемуся за свободу Дона, Полковнику Чернецову и другим орлам-партизанам. Памятник должен от- 
вечать величию идей борьбы за родину, быть согласован с исторической правдой и олицетворять всех героев освободительной войны как в общей группе, так и в особых символах» [15, с. 282]. Средства на постройку памятника должен был дать «кружечный сбор». Все отделения Государственного банка обязывались принимать такого рода пожертвования.

Учреждался конкурс на устройство памятника: проекты в эскизах, набросках и планах или в уменьшенных моделях должны были быть представлены к 1 февраля 1920 г. на имя директора Донского музея. Три премии лучшим проектам присуждало «жюри из лучших художественных сил». Предписывалось также увековечить памятниками «места особо памятных боев, покрывших славою Донское оружие», изыскав деньги «по особой подписке в округах» $[15$, с. 283$]$.

Через год, уже при новом атамане А.П. Богаевском, было произведено освящение территории под постройку памятника на месте мученической кончины его брата М.П. Богаевского в Балабановской роще близ Нахичевани. В присутствии атамана, родственников, епископа, членов правительства и Войскового Круга, представителей городского самоуправления Ростова-на-Дону и Нахичевани были проведены торжественное богослужение и военный парад. Интересно, что епископ Гермоген в речи перед богослужением сделал акцент на том, что «павший от злодейской руки тягчайших преступников» М.П. Богаевский, равно как и атаман А.М. Каледин, «трудились для одного великого дела - воссоздания единой, великой и неделимой России», что «Тихий Дон без России, как и Россия без Дона существовать не могут» [22, с. 3]. Таким образом, в связи с «продобровольческим» курсом трансформировались представления о донских героях Гражданской войны. Теперь они должны были быть борцами не только «за свободу Родного Края» (как во времена П.Н. Краснова), но и за единую Россию.

В южнороссийской прессе печатались воззвания общественных организаций, инициативных групп о сборе денег на памятники Л.Г. Корнилову, М.В. Алексееву и другим героям Белого движения. Планировалось строительство церквей памяти павших в кровавой междоусобице. В упомянутой выше речи епис- копа Гермогена упоминалось об освящении «в стольном граде Донской земли... места храма спасения Дона от ига и жестокостей большевизма на месте мученической кончины донских атаманов и лучших деятелей и граждан Донского казачества» [22, с. 3]. Действующие храмы стали местами упокоения героев Гражданской войны: в кафедральном соборе св. Екатерины в Екатеринодаре похоронили М.В. Алексеева, М.Г. Дроздовского, К.К. Мамантова, в Вознесенском кафедральном соборе Новочеркасска (на военном кладбище) - С.Л. Маркова.

После объявленного конкурса на проект часовни на военном кладбище Екатеринодара в память воинов Добровольческой армии, эскиз известного столичного архитектора А.А. Оля, жившего тогда на Юге, был опубликован в ростовском журнале «Орфей» (1919, № 1, с. 71). Коллега А.А. Оля - А.А. Юнгер в жизнеописании, составленном в 1919 г. для поступления на работу в Кубанский политехнический институт, указывал, что «проектировал памятник борцам за свободу для города Екатеринодара» [25, л. 15 об.]. Еще один столичный архитектор - С.С. Кричинский в июле 1919 г. представил эскизы проекта памятника-храма на могиле генерала Корнилова «в русском стиле XVIII века», «похожего на храм в Филях под Москвой», который планировалось возвести после окончания Гражданской войны «путем всероссийской подписки»; в ближайшее время было решено ограничиться часовней [19, л. 12].

Обозначенные монументальные проекты, в отличие от «ленинского плана монументальной пропаганды», остались на бумаге ввиду исхода Гражданской войны.

Имена героев антисоветского движения увековечивались в названиях многочисленных воинских подразделений. Имелись агитпоезда имени Каледина и имени Корнилова, легкий бронепоезд «Генерал Марков», корабли «Генерал Алексеев», «Генерал Корнилов», благотворительные организации - Корниловский и Алексеевский комитеты. Антибольшевистские походы отразились в наградах: Знак отличия 1-го Кубанского (Ледяного) похода, медаль «Похода дроздовцев», крест «За Степной поход», крест «За спасение Кубани», медаль «За освобождение Кубани». 
Принимались решения о переименовании улиц и даже населенных пунктов. К первой годовщине освобождения Кубани от большевиков планировалось строительство нового городка (около места гибели Л.Г. Корнилова) с названием Корниловск, переименование главной улицы Екатеринодара - Красной в улицу Добровольческой Армии, площади у Екатерининского собора - имени М.В. Алексеева [19, л. 12]. Поселок на месте гибели С.Л. Маркова у станции Торговой стал городом под названием Марков (в 1920 г. переименован в Сальск), поселок Миллерово на несколько месяцев 1919 г. превратился в город Каледин.

Укоренению в сознании молодежи представления об истинных героях Гражданской войны должно было способствовать присвоение учебным заведений имен участников (как погибших, так и живых) антисоветского движения, назначение именных стипендий, которые получали, как правило, продолжавшие обучение участники боевых действий или их прямые потомки. Начало этому положил упомянутый выше приказ атамана П.Н. Краснова от 5 сентября 1918 г.: Донской политехнический институт стал именоваться «имени Войскового Атамана Алексея Максимовича Каледина», Донской университет (несколько лет назад эвакуированный из Варшавы) имени М.П. Богаевского, Донской ветеринарный институт (тоже в годы Первой мировой войны эвакуированный с польских территорий) - имени А.М. Назарова, Донской учительский институт - имени «павших за освобождение родного края». Этим же именем должно было называться одно среднее учебное заведение в каждой из окружных станиц. Учреждалось несколько стипендий имени А.М. Каледина, М.П. Богаевского, А.М. Назарова, В.М. Чернецова [15, с. 283].

Тот же П.Н. Краснов, публично отзывавшийся о покойных лидерах Добровольческой армии крайне комплементарно, после смерти М.В. Алексеева издал приказ об увековечении памяти «великого человека», бывшего «связующим звеном при выполнении государственных задач Донскими и Добровольческими армиями», необходимо объявить подписку для учреждения при Донском кадетском корпусе трех стипендий имени Алексеева для детей героев настоящей освободительной борьбы как Донских казаков, так и Добровольческой Армии». Имя Алексеева присваивалось также лазарету № 7, «как служившему преимущественно для лечения добровольцев» [16, с. 410-411].

На рубеже 1918-1919 гг. было принято решение учредить в создаваемом Кубанском политехническом институте (правительственном) стипендии имени действующих казачьих политиков генерал-лейтенанта А.П. Филимонова, Н.С. Рябовола, Ф.А. Щербины (видного ученого, автора «Истории Кубанского казачьего войска»), Л.Л. Быча и стипендию имени убитых большевиками отца и сыновей Бардижей в Брюховецком реальном училище. Имена генералов С.Л. Маркова, Л.Г. Корнилова, М.В. Алексеева и генерал-лейтенанта А.П. Филимонова присваивались учебным заведениям станицы Ильской, имя А.Г. Шкуро - училищу станицы Суворовской [17, л. 184, 317, 321, 325].

Как видим, кубанский и отчасти донской «перечни» героев войны, несмотря на явное преобладание регионального компонента, свидетельствовали о попытке достижения компромисса посредством мемориальной политики. Однако противоречия, связанные с различными взглядами на государственное устройство будущей России, неизбежно вырывались на поверхность.

Например, герои кубанского казачества Л.Л. Быч и Н.С. Рябовол были постоянной мишенью критики в проденикинских газетах. Прозвища «бычевол», «Лукавый Бык» и «Вол Рябой», с легкой руки журналистов, стали почти обиходными. Не случайно на заседании Рады 14 июня 1919 г., сразу после убийства Н.С. Рябовола, депутат Жук предложил «закрыть все газеты, травившие покойного, редакторов же выслать», а депутат Белый - «закрыть все организации, которые занимаются травлей кубанского казачества и его лучших представителей», прежде всего деникинский Осваг [21, с. 354].

В то время как Кубанское краевое правительство организовывало пышные похороны Н.С. Рябовола, объявляло трехдневный траур, учреждало новые стипендии его имени, а почти в каждом номере «Вольной Кубани» (органе Кубанского краевого правительства) печатались приговоры станичных сборов, облича- 
ющих монархистов, спрятавшихся под маской борцов за единую Россию, убивших героя, патриота «родного края» и постановлявших назвать в честь Н.С. Рябовола станичные учебные заведения, в «добровольческой» прессе его смерть обсуждалась без всякого пафоса, как событие криминальной хроники. Вообще печатная продукция Юга России как «место памяти», вкупе с рассмотренными выше коммеморациями, свидетельствуют о наличии оппонирующих мемориальных дискурсов.

После окончания Гражданской войны на Кубани и Дону, как и в других центрах гражданского противостояния, началась активная мемориализация и героизация жертв «контрреволюции». Советская политика памяти имела целью унифицировать коллективные представления о недавнем военно-революционном прошлом, вытеснить «вредные» исторические образы и оценки из коллективной памяти, а также насадить новый героический пантеон и нарратив, в том числе посредством музейных экспозиций [6, с. 303, 308, 393]. Мемориализация антисоветского движения в эмиграции проводилась конкурирующими политическими силами; музеи и архивы, периодические издания, коммеморативные ритуалы представляли различные версии истории гражданского противостояния. Различались и персонажи пантеонов героев.

В начале нынешнего века на официальном уровне за Гражданской войной (как и за Октябрьской революцией) был закреплен статус травмы; ее жертвами объявлены все участники и мирное население. Монументальным воплощением данного статуса стали памятники примирения и согласия, установленные в том числе в казачьих столицах - Краснодаре (бывшем Екатеринодаре) и Новочеркасске. Собственные трактовки истории Гражданской войны на Юге России представляют идеологи различных политических сил, возрожденного казачества, что воплощается в содержании научной и популярной литературы, музейных экспозиций, коммеморативных инициативах. Несмотря на появившиеся памятники С.Л. Маркову (в Сальске), Л.Г. Корнилову и Ф.А. Щербине (в Краснодаре), количественное преобладание объектов, посвященных «красным», очевидно [2]. Практически все монументальные и топонимические проекты, связанные с мемориализацией антисоветского движения, вызывают жаркие дискуссии. Нередко это детерминировано фактором сотрудничества героизируемых лиц (таких как П.Н. Краснов или А.И. Шкуро) с нацистами. Имеет место также приверженность значительной части населения, особенно старшего поколения, советской трактовке истории Гражданской войны. Как и столетие назад, в обществе циркулируют оппонирующие нарративы, препятствующие провозглашенному властной элитой «примирению и согласию».

Результаты. Память об эпохе гражданского противостояния на Юге России активно конструировалась уже в процессе Гражданской войны. Руководство «белого» и казачьих государственных образований, равно как и большевики, видели в этом значительный пропагандистский потенциал. Мемориальная политика являлась частью собственной легитимации антисоветских правительств. Не случайно инициативы властных структур в этом направлении широко освещалась в прессе.

Важной составляющей мемориальной политики стало увековечение жертв борьбы с большевиками, создание «мест памяти». Наиболее последовательными были коммеморативные акции, посвященные Л.Г. Корнилову, воплощавшему «универсального» героя. Годовщина гибели Корнилова положила начало новым памятным датам и дала мощный толчок деятельности Военно-исторической комиссии при деникинском Отделе пропаганды в плане сбора артефактов по истории Белого движения для будущего Всероссийского музея.

Казачьи правительства, заинтересованные в определенной интерпретации событий братоубийственной войны, предприняли попытки создания собственных музеев, аккумулировавших материалы по новейшей истории.

Передвижная Корниловская выставка стала практически единственным реализованным на территории Дона и Кубани пропагандистским музейным проектом. В процессе ее подготовки и проведения была налажена координация деникинского и казачьих правительств, представителей действующей армии. Выставка представлялась в прессе как демонстрация единства антибольшевистских сил.

В ряду мемориальных практик изучаемого периода - монументальные, топоними- 
ческие и иные инициативы, направленные на создание пантеона героев, включавшего военачальников и политиков Белого движения и казачества - погибших и действующих. Похороны, перезахоронения, поминовения организовывались как массовые действа. Места гибели павших героев становились сакральными. Анонсировались конкурсы на проекты памятников и храмов. Представления об истинных героях посредством присвоения их имен учебным заведениям, именных стипендий укоренялись в сознании молодежи.

Следствием серьезных противоречий между главными акторами антибольшевистского лагеря стало формирование оппонирующих мемориальных нарративов на Юге России. Мемориализация антисоветского движения, продолженная в эмиграции и в постсоветской России, на всех этапах вызывала острые дискуссии ввиду «конфликтов памяти».

\section{ПРИМЕЧАНИЕ}

${ }^{1}$ Статья подготовлена в рамках выполнения государственного задания Южного филиала ФГБНИУ «Российский научно-исследовательский институт культурного и природного наследия имени Д.С. Лихачева» по теме «Монументальная политика как инструмент сохранения культурной памяти».

The article was carried out within State task of the Southern Branch of Russian Research Institute for Cultural and Natural Heritage named after D.S. Likhachev "Monumental politics as a tool for preserving cultural memory".

\section{СПИСОК ЛИТЕРАТУРЫ}

1. Выставка памяти ген[ерала] Корнилова // Приазовский край. - 1919. - 14 (27) мая. - С. 4.

2. Гончаров, А. В. «Победителям и побежденным»: эпоха гражданского противостояния на Кубани и Черноморье в объектах культурного наследия / А. В. Гончаров // Наследие веков. - 2018. № 2. - С. 41-47. - Электрон. текстовые дан. - Режим доступа: http://heritage-magazine.com/wpcontent/uploads/2018/06/2018_2_Goncharov.pdf (дата обращения: 28.05.2019). - Загл. с экрана.

3. Донской атаман на Корниловской выставке // Приазовский край. - 1919. - 24 мая (6 июня). C. 2 .

4. Еремеева, А. Н. «Дабы сохранить воспоминания о переживаемых событиях»: у истоков фор- мирования музейных и архивных коллекций по истории Революции и Гражданской войны / А. Н. Еремеева // Кубань в эпоху великих потрясений. 19171920 гг. Фелицынские чтения - XIX : материалы Межрегион. науч.-практ. конф. - Краснодар : Вика-принт, 2017. - C. $45-48$.

5. Корсакова, Н. А. К вопросу о создании в г. Екатеринодаре музея борьбы с большевизмом / Н. А. Корсакова // Кубань в эпоху великих потрясений. 1917-1920 гг. Фелицынские чтения - XIX : материалы Межрегион. науч.-практ. конф. - Краснодар : Вика-принт, 2017. - С. 74-75.

6. Красильникова, Е. И. Помнить нельзя забыть? Памятные места и коммеморативные практики в городах Западной Сибири (конец 1919 - середина 1941 г.) / Е. И. Красильникова. - 2-е изд. Новосибирск : ИЦ НГАУ «Золотой колос», 2015. $404 \mathrm{c}$.

7. Краткий очерк возникновения и деятельности Военно-исторической комиссии // Государственный архив Российской Федерации (ГАРФ). Ф. Р-440. - Оп. 1. - Д. 79. - 2 л.

8. Леонтьева, О.Б. «Мемориальный поворот» в современной российской исторической науке / О. Б. Леонтьева // Диалог со временем. - 2015. № 50.- С. 59-96.

9. Малинова, О. Ю. Коммеморация столетия революции(й) 1917 года в РФ: сравнительный анализ соперничающих нарративов / О. Ю. Малинова // Полис. Политические исследования. - 2018. № 2. - C. 37-56. - DOI: https://doi.org/10.17976/jpps/ 2018.02.04.

10. Нора, П. Проблематика мест памяти / П. Нора // Франция-память. - СПб. : Изд-во С.-Петерб. ун-та, 1999. - С. 17-50.

11. Об учреждении при Донском университете архива документов, относящихся к переживаемому нами смутному времени // Государственный архив Ростовской области (ГАРО). - Ф. 493. - Оп. 1. Д. 118. - Л. 31-32.

12. О собирании материалов по переживаемому моменту // Педагогическая мысль. - 1918. 25 сент. - С. 34.

13. Переписка Отдела осведомления Всевеликого войска Донского с Донским обществом партизан, начальником Атаманского военного училища и другими о сборе экспонатов и организации выставки // Государственный архив Российской Федерации (ГАРФ). - Ф. Р-6053. - Оп. 1. - Д. 4. - 59 л.

14. Переписка с начальником штаба Донской армии об организации и открытии выставки и список экспонатов для выставки // ГАРФ. - Ф. Р-6053. Оп. 1. - Д. 5. - 37 л.

15. Приказ Всевеликому Войску Донскому № 898, 5 сентября 1918 г. // Сборник узаконений правительства Всевеликого Войска Донского и важней- 
ших распоряжений Донского атамана с хронологическим и алфавитным указателями. Вып. 5. - Новочеркасск : [б. и.], 1919. - С. 282-284.

16. Приказ Всевеликому Войску Донскому № 1331, 28 октября 1918 г. (по военному отделу) // Сборник узаконений правительства Всевеликого Войска Донского и важнейших распоряжений Донского атамана с хронологическим и алфавитным указателями. Вып. 5. - Новочеркасск : [б. и.], 1919. C. $410-411$.

17. Приказы ведомства народного просвещения // Государственный архив Краснодарского края (ГАКК). - Ф. Р-6. - Оп. 1. - Д. 179. - 356 л.

18. Протокол № 41 Заседания Совета Кубанского Краевого Правительства, 11 октября 1918 г. // Протоколы заседаний Кубанского краевого правительства: 1917-1920 : сб. док. в 4 т. / под ред. А. А. Зайцева. - Краснодар : [б. и.], 2008. - Т. 1. C. 131-133.

19. Протокол организационного собрания по поводу предстоящей годовщины освобождения Екатеринодара от большевиков // ГАКК. - Ф. Р-7. Оп. 1. - Д. 576. - Л. 8-13.

20. Прошения о высылке фотографий и копий с них // ГАКК. - Ф. 396. - Оп. 5. - Д. 585. - 28 л.

21. Стенограмма заседания Кубанской Законодательной Рады от 14 июня 1919 года // Протоколы и стенограммы заседаний Кубанских краевой и Законодательной Рад: 1917-1920 гг. : сб. док. в 6 т. / под ред. А. А. Зайцева. - Краснодар : Перспективы образования, 2016. - Т. 5. - С. 352-356.

22. Увековечение памяти М.П. Богаевского // Приазовский край. - 1919. - 8 (21) сент. - С. 3 .

23. Цветков, В. Ж. Мемориальные экспозиции по истории Белого движения в России в $1917-$ 1920-е годы (проекты реализованные и разработанные) / В. Ж. Цветков // Профессионализм педагога: сущность, содержание, перспективы развития : материалы Междунар. науч.-практ. конф., посвящ. 130-летию со дня рождения А.С. Макаренко. - М. : Международная академия наук педагогического образования, 2019. - С. 372-378.

24. Циркулярное предписание командира белогвардейского 3-го конного корпуса от 29 сентября 1919 г. о создании музея Кубанского казачьего войска и сборе материалов для музея // Российский государственный военный архив. - Ф. 39704. Оп. 1. - Д. 9. - Л. 1-2.

25. Юнгер Александр Александрович // ГАКК. Р-229. - Оп. 1. - Д. 660. - Л. 15-15 об.

26. 22 prints depicting the Kornilov Exhibition, 1919 // Hoover Institution Archives (HIA). Evgenii Miller papers. - File 28007. - Photographs, 1916-1924. - Envelope C.

27. Heretz, L. Psychology of the White movement / L. Heretz // The Bolsheviks in Russian society / ed.:
V. Brovkin. - New Haven : Yale University Press, 1997. - P. 105-121.

28. Lisovoi, I. M. Letter to B. Nicolaevsky, 1951 / I. M. Lisovoi // HIA. - B.I. Nicolaevsky Collection. Box 489. - Folder 12.

\section{REFERENCES}

1. Vystavka pamyati generala Kornilova [Exhibition in Memory of General Kornilov]. Priazovskij kraj [Azov Region], 1919, May 14 (27), p. 4.

2. GorchakovA.V. «Pobediteljami pobezhdennym»: jepoha grazhdanskogo protivostojanija na Kubani i chernomore v obektah kulturnogo nasledija ["To Winners and Losers": the Epoch of Civil Confrontation in Kuban and in the Black Sea Region in the Objects of Cultural Heritage]. Naslediye vekov [Heritage of Centuries], 2018, no. 2, pp. 41-47. URL: http:/heritage-magazine.com/wp-content/uploads/ 2018/06/2018_2_Goncharov.pdf (accessed 28 May 2019).

3. Donskoj ataman na Kornilovskoj vystavke [The Don Ataman for the Kornilov Exhibition]. Priazovskij kraj [Azov Region], 1919, May 24 (June 6), p. 2.

4. Eremeeva A.N. «Daby sohranit vospominanija o perezhivaemyh sobytijah»: $\mathrm{u}$ istokov formirovanija muzejnyh i arhivnyh kollekcij po istorii Revoljucii i Grazhdanskoj vojny ["In Order to Preserve the Memories of Experienced Events": The First Steps in the Formation of Museum and Archival Collections on the History of the Revolution and the Civil War]. Kuban v jepohu velikih potrjasenij. 1917-1920 gg. Felicynskie chtenija - XIX: materialy Mezhregion. nauch.-prakt. konf. [Kuban in an Era of Great Upheaval. 1917-1920. Felicyn's Readings - XIX. Proc. of the Interregional Scientific and Practical Conf.]. Krasnodar, Vika-print Publ., 2017, pp. 45-48.

5. Korsakova N.A. K voprosu o sozdanii v g. Ekaterinodare muzeja borby s bolshevizmom [To the Question of Creation of the Museum of Struggle Against Bolshevism in Ekaterinodar]. Kuban v jepohu velikih potrjasenij. 1917-1920 gg. Felicynskie chtenija-XIX: materialy Mezhregion. nauch.-prakt. konf. [Kuban in an Era of Great Upheaval. 1917-1920. Felicyn's Readings - XIX. Proc. of the Interregional Scientific and Practical Conf.]. Krasnodar, Vika-print Publ., 2017, pp. 74-75.

6. Krasilnikova E.I. Pomnit nelzja zabyt? Pamjatnye mesta i kommemorativnye praktiki $v$ gorodah Zapadnoj Sibiri (konec 1919 - seredina 1941 g.) [Remember not to Forget? Memorable Places and Commemorative Practices in the Cities of Western Siberia (Late 1919-Mid 1941)]. Novosibirsk, ITs NSTU «Zolotoj kolos», 2015. 404 p. 
7. Kratkij ocherk vozniknovenija i dejatelnosti Voenno-istoricheskoj komissii [A Brief Outline of the Appearance and Activities of the Military History Commission]. Gosudarstvennyj arhiv Rossijskoj Federacii [State Archive of the Russian Federation], f. R-440, op. 1, d. 79. 21.

8. Leonteva O.B. «Memorialnyj povorot»v sovremennoj rossijskoj istoricheskoj nauke ["Memorial Turn" in the Contemporary Russian Historical Studies]. Dialog so vremenem [Dialogue with Time], 2015, no. 50, pp. 59-96.

9. Malinova O.Yu. Kommemoracija stoletija revoljucii(j) 1917 goda v RF: sravnitelnyj analiz sopernichajushhih narrativov [The Commemoration in Russia of the Centenary of the 1917 Revolution(s): Comparative Analysis of Rival Narratives]. Polis. Politicheskie issledovanija [Polis. Political Studies], 2018, no. 2, pp. 37-56. DOI: 10.17976/jpps/2018.02.04.

10. Nora P. Problematika mest pamiati [Problems of Sites of Memory]. Frantsiia-pamiat [FranceMemory]. Saint Petersburg, Izd-vo SanktPeterburgskogo universiteta, 1999, pp. 17-50.

11. Ob uchrezhdenii pri Donskom universitete arhiva dokumentov otnosjashhihsja k perezhivaemomu name smutnomu vremeni [About Establishment of Archive of the Documents Relating to the Current Time of Troubles at the Don University]. Gosudarstvennyj arhiv Rostovskoj oblasti [State Archive of Rostov Region], f. 493, op. 1, d. 118, 1.31-32.

12. O sobiranii materialov po perezhivaemomu momentu [About Collecting Materials on the Experienced Moment]. Pedagogicheskaya mysl [Pedagogical Thought], 1918, September 25, p. 34.

13. Perepiska Otdela osvedomleniya Vsevelikogo voyska Donskogo s Donskim obshchestvom partisan, nachalnikom Atamanskogo voennogo uchilishcha i drugimi o sbore eksponatov i organizatsii vystavki [Correspondence of Department of Awareness of the All-Great Army of Don with the Don Partisan Society, the Chief of the Ataman Military School and the Other for Collection of the Exhibits, and Organization of the Exhibition]. Gosudarstvennyj arhiv Rossijskoj Federacii [State Archive of the Russian Federation], f. R-6053, op. 1, d. 4. 591.

14. Perepiska s nachalnikom shtaba Donskoy armii ob organizatsii i otkrytii vystavki i spisok eksponatov dlya vystavki [Correspondence with the Chief of Staff of the All-Great Army of Don on the Organization and Opening of the Exhibition and the List of Exhibits for the Exhibition]. Gosudarstvennyj arhiv Rossijskoj Federacii [State Archive of the Russian Federation], f. R-6053, op. 1, d. 5. 371.

15. Prikaz Vsevelikomu Voysku Donskomu № 898, 5 sentyabrya $1918 \mathrm{~g}$. [Order to the All-Great Army of Don No. 898, September 5, 1918]. Sbornik uzakoneniy pravitelstva Vsevelikogo Voyska Donskogo $i$ vazhneyshikh rasporyazheniy Donskogo atamana s khronologicheskim i alfavitnym ukazatelyami [Collection of Laws of the Government of the All-Great Army of the Don and the Most Important Orders of the Don Ataman with Chronological and Alphabetical Indexes], Novocherkassk, 1919, iss. 5, pp. 282-284.

16. Prikaz Vsevelikomu Voysku Donskomu № 1331, 28 oktyabrya 1918 g. (po voennomu otdelu) [Order to the All-Great Army of Don No. 1331, October 28, 1918 (Military Division)]. Sbornik uzakoneniy pravitelstva Vsevelikogo Voyska Donskogo i vazhneyshikh rasporyazheniy Donskogo atamana $s$ khronologicheskim i alfavitnym ukazatelyami [Collection of Laws of the Government of the All-Great Army of the Don and the Most Important Orders of the Don Ataman with Chronological and Alphabetical Indexes], Novocherkassk, 1919, iss. 5, pp. 410-411.

17. Prikazy vedomstva narodnogo prosveshcheniya [Orders of the Department of Public Education]. Gosudarstvennyy arkhiv Krasnodarskogo kraya [State Archive of Krasnodar Region], f. R-6, op. 1, d. 179.3561 .

18. Protokol № 41 Zasedaniya Soveta Kubanskogo Kraevogo Pravitelstva 11 oktyabrya 1918 g. [Protocol No. 41 of the Meeting of the Council of the Kuban Regional Government, October 11, 1918]. Zaytsev A.A., ed. Protokoly zasedaniy Kubanskogo kraevogo pravitelstva: 1917-1920: sb. dok. $v 4 t$. [Protocols of the Meetings of the Kuban Regional Government: 19171920. Collection of Documents in 4 Volumes]. Krasnodar, 2008, vol. 1, pp. 131-133.

19. Protokol organizatsionnogo sobraniya po povodu predstoyashchey godovshchiny osvobozhdeniya Ekaterinodara ot bolshevikov [Protocol of the Organizational Meeting on the Upcoming Anniversary of the Liberation of Ekaterinodar from the Bolsheviks]. Gosudarstvennyy arkhiv Krasnodarskogo kraya [State Archive of Krasnodar Region], f. R-7, op. 1, d. 576, 1. 8-13.

20. Prosheniya o vysylke fotografiy $i$ kopiy s nikh [Petitions for Expulsion Photos, Groups, and Copies of Them]. Gosudarstvennyy arkhiv Krasnodarskogo kraya [State Archive of Krasnodar Region], f. 396, op. 5, d. 585.281.

21. Stenogramma zasedaniya Kubanskoy Zakonodatelnoy Rady ot 14 iyunya 1919 goda [Transcript of the Meeting of the Kuban Legislative Council of June 14, 1919]. Zaitsev A.A., ed. Protokoly $i$ stenogrammy zasedaniy Kubanskikh kraevoy $i$ Zakonodatelnoy Rad: 1917-1920 gg.: sb. dok. $v 6 t$. [Protocols and Transcripts of Meetings of the Kuban Regional and Legislative Council: 1917-1920. Collection of Documents in 6 Volumes]. Krasnodar, Perspektivy obrazovaniya, 2016, vol. 5, pp. 352-356.

22. Uvekovechenie pamyati M.P. Bogaevskogo [Perpetuation of the Memory of M.P. Bogaevsky], 
Priazovskij kraj [Azov Region], 1919, September 8 (21), p. 3.

23. Tsvetkov V.Zh. Memorialnye ekspozitsii po istorii Belogo dvizheniya v Rossii v 1917-1920-e gody (proekty realizovannye i razrabotannye) [Memorial Expositions on the History of the White Movement in Russia in the 1917-1920s (Implemented and Developed Projects)]. Professionalizm pedagoga: sushchnost, soderzhanie, perspektivy razvitiya: materialy Mezhdunar. nauch.-prakt. konf., posvyashch. 130-letiyu so dnya rozhdeniya A.S. Makarenko [Proc. Int. Conf. "Professionalism of the Teacher: Essence, Content, Development Prospects", Devoted to the $130^{\text {th }}$ Anniversary of A.S. Makarenko]. Moscow, Mezhdunarodnaia akademiia nauk pedagogicheskogo obrazovaniia, 2019, pp. 372-378.

24. Tsirkulyarnoe predpisanie komandira belogvardeyskogo 3-go konnogo korpusa ot 29 sentyabrya 1919 g. o sozdanii muzeya Kubanskogo kazachego voyska i sbore materialov dlya muzeya [Circular Order of the Commander of the
White Guard 3 Horse Corps of September 29, 1919 on the Creation of the Museum of the Kuban Cossack Army and the Collection of Materials for the Museum]. Rossiyskiy gosudarstvennyy voennyy arkhiv [Russian State Military Archive], f. 39704, op. 1, d. 9, 1. 1-2.

25. Yunger Aleksandr Aleksandrovich. Gosudarstvennyy arkhiv Krasnodarskogo kraya [State Archive of Krasnodar Region], f. R-229, op. 1, d. $660,1.15-15 \mathrm{rev}$.

26. 22 Prints Depicting the Kornilov Exhibition, 1919. Hoover Institution Archives, Evgenii Miller papers, File 28007, Photographs, 1916-1924, Envelope C.

27. Heretz L. Psychology of the White Movement. V. Brovkin, ed. The Bolsheviks in Russian Society, New Haven, Yale University Press, 1997, pp. 105-121.

28. Lisovoi I. M. Letter to B. Nicolaevsky, 1951. Hoover Institution Archives, B.I. Nicolaevsky Collection, Box 489, Folder 12.

\section{Information About the Author}

Anna N. Eremeeva, Doctor of Sciences (History), Professor, Chief Researcher, Department for Complex Problems for Cultural Research, Southern Branch of Russian Research Institute for Cultural and Natural Heritage named after D.S. Likhachev, Krasnaya St, 28, 350000 Krasnodar, Russian Federation, erana@mail.ru, https://orcid.org/0000-0002-1267-0074

\section{Информация об авторе}

Анна Натановна Еремеева, доктор исторических наук, профессор, главный научный сотрудник отдела комплексных проблем изучения культуры, Южный филиал Российского научноисследовательского института культурного и природного наследия им. Д.С. Лихачева, Красная, 28, 350000 г. Краснодар, Российская Федерация, erana@mail.ru, https://orcid.org/0000-0002-1267-0074 